\begin{tabular}{|l|l|l||}
\hline \multicolumn{2}{|c|}{ PublisherInfo } \\
\hline \hline PublisherName & $:$ & BioMed Central \\
\hline \hline PublisherLocation & $:$ & London \\
\hline \hline PublisherImprintName & $:$ & BioMed Central \\
\hline \hline
\end{tabular}

\title{
Targeted methylation
}

\begin{tabular}{|l|l|l||}
\hline \multicolumn{2}{|c|}{ ArticleInfo } \\
\hline \hline ArticleID & $:$ & 3869 \\
\hline \hline ArticleDOI & $:$ & $10.1186 /$ gb-spotlight-20001221-01 \\
\hline \hline ArticleCitationID & $:$ & spotlight-20001221-01 \\
\hline \hline ArticleSequenceNumber & $:$ & 306 \\
\hline \hline ArticleCategory & $:$ & Research news \\
\hline ArticleFirstPage & $:$ & 1 \\
\hline \hline ArticleLastPage & $:$ & 2 \\
\hline \hline & & RegistrationDate : 2000-12-21 \\
ArticleHistory & $:$ & OnlineDate $\quad$ 2000-12-21 \\
\hline \hline ArticleCopyright & $:$ & BioMed Central Ltd2000 \\
\hline \hline ArticleGrants & $:$ & \\
\hline \hline ArticleContext & $:$ & 130591111 \\
\hline \hline
\end{tabular}




\section{Jonathan Weitzman}

Email: jonathanweitzman@hotmail.com

Methylation of DNA at $\mathrm{CpG}$ dinucleotides represses gene transcription. Methylation plays an important role in development, imprinting, $\mathrm{X}$-chromosome inactivation and tissue-specific gene expression, but the mechanisms of methylation-induced repression are still unclear. In the December Molecular and Cellular Biology, Schubeler et al. show that localized histone deacetylation can explain methylation-induced repression ( $\mathrm{Mol} \mathrm{Cell} \mathrm{Biol} \mathrm{2000,} \mathrm{20:9103-9112).} \mathrm{The} \mathrm{authors} \mathrm{used} \mathrm{an} \mathrm{elegant}$ technique called recombinase-mediated cassette exchange (RMCE) to introduce in vitro-methylated DNA at defined chromosomal positions. They used the Cre recombinase to insert methylated or unmethylated forms of the human $\beta$-globin gene promoter driving a green fluorescent protein (GFP) reporter gene. Methylation repressed GFP expression, and was stable in cells over at least 12 weeks in culture. Methylation did not affect DNA replication or global chromatin remodeling. However, methylation caused a hypoacetylation of histones $\mathrm{H} 3$ and $\mathrm{H} 4$ within the transgene. These observations support a model in which methylated DNA represses local transcription by recruiting histone deacetylase activity.

\section{References}

1. CpG methylation, chromatin structure and gene silencing-a three-way connection.

2. Molecular and Cellular Biology, [http://www.intl-mcb.asm.org]

3. Site-specific chromosomal integration in mammalian cells: highly efficient CRE recombinasemediated cassette exchange. 